\title{
Determinants of Political Stability to Support Foreign Investment in Indonesia
}

\author{
Benny Budiawan Tjandrasa \\ Maranatha Christian University \\ J1. Surya Sumantri No. 65, Sukawarna, Sukajadi, Bandung 40164, Indonesia \\ Email: benny.tjandrasa@gmail.com; benny.budiawan@eco.maranatha.edu \\ Phone: (+62) 878-2399-9789
}

\begin{abstract}
What investors often consider before deciding to invest in various countries is the political situation. The risks faced by investors in the event of political instability are regulatory changes, legal disputes, forced takeovers of companies, disruption to regional stability, policies against acts of terrorism, and changes in state ideology. The purpose of this study is to find a determinant of political stability in Indonesia that will be useful for investors and multinational companies, and the government in maintaining political stability. Systematic secondary data sampling from January 2015 to December 2019 was used for explanatory study purposes and to build a model. This study concludes that the rule of law, control of corruption, and oil prices have a significant effect on political stability in Indonesia, while the inflation rate does not have a significant effect on political stability in Indonesia. The novelty of this research is the formation of a political stability model for Indonesia and why an increase in control of corruption actually has a negative effect on political stability in Indonesia.
\end{abstract}

Keywords: Political; Corruption; Investment; Inflation.

JEL codes: D72, D73, E22, E31, O53

\section{Introduction}

In the current era of free trade and globalization, foreign investment is the desire of the governments of all countries because foreign investment will provide enormous foreign exchange, sophisticated infrastructure development, and absorb a lot of labor. Moreover, the expectation for investments increases the competitiveness of a country in the current era of global competition. However, investors always look for a place to invest that generates a rate of return that meets their expectations.

Head of the Badan Koordinasi Penanaman Modal (Investment Coordinating Board), Thomas Trikasih Lembong, said one of the essential factors for foreign investors to be confident to invest in a country is to improve political stability in the country (Sicca, 2018). The statement is based on a seminal study that states a democratic government will be more attractive to foreign investors (Jensen, 2003). This is in line with a study in the Middle East that states that political stability is essential for Yemen's future economic growth (Musibah et al., 2015). The study results in sub-Saharan Africa even added another factor besides macroeconomics and political stability needed to attract foreign investment, which is institutional credibility (Cleeve, 2012; Tjandrasa et al., 2020). Research conducted in Indonesia also concluded that foreign investors are very sensitive to political conditions (Tjandrasa, 2019).

In Indonesia, the problem of institutional credibility is one of the biggest problems faced by the country. After decades of uncontrolled corruption during the New Order administration, corruption practices have penetrated from the lowest to the highest level of government (Hadi, 2016). As a result, the KPK (Corruption Eradication Commission) was formed (Wardojo, 2018). The function of KPK is also to restore public trust in legal institutions in Indonesia (Wattimena, 2016). Center for Indonesian Policy Studies (CIPS) researcher, Pingkan Audrine Kosijungan, said that an important factor in the country that should be considered is the stability of socio-political conditions that impact investment growth (Setyaningrum, 2019). What is meant by this social-political condition is that the social condition of society and the political situation can affect each other.

Political sociology studies the relationship between political activities and people's lives because political activities are inseparable from the social situation of society (Dewi, 2017). Political turmoil in a country generally starts from the economic condition in the country (Rudolfsen, 2021). Hyperinflation and the surge in petroleum 
prices can lead to political instability, leading to regulatory changes, legal disputes, and forced takeovers of companies as happened to Repsol Company in Bolivia and Venezuela (Berrios et al., 2011). If political instability becomes increasingly uncontrollable, it can develop into acts of terrorism, change in state ideology, and eventually disruption to regional stability as it once did in Egypt and Tunisia (Abdelaty \& Esmail, 2016).

Foreign investors and especially multinational companies also monitor developments in the destination country before deciding to invest. One of the factors that are often considered from a particular country or region is the political development in the country because multinational companies face a great risk stemming from the uncertainty of the political situation in the destination country. Commonwealth Bank's Head of Wealth Management \&Client Growth, Ivan Jaya, said Indonesia was a global investor's leading investment destination but hoped for stable Indonesian political conditions (Wuryasti, 2019; Tjandrasa et al., 2020). Associate Director of Colliers Inter-national Indonesia, Ferry Salanto, said many investors were delaying their investments ahead of the general election. He also said the importance of political certainty, low levels of corruption, and a guaranteed level of security to encourage the influx of foreign investment (Haryanti, 2019). Head of Biro Pusat Statistik (Central Bureau of Statistics), Suhariyanto, stated that political instability will greatly affect investment interest, and the unstable political situation in Indonesia some time ago led to a decline in the level of investment in Indonesia (Makki, 2019). Soelaeman Soemawinata, who is the Chairman of DPP Real Estate Indonesia (REI), also expressed his hope that political stability can support the growth of the property industry (Haryanti, 2019). So, one of the important things that the Indonesian government must do is to maintain the stability of economic and political conditions. Guaranteed political stability will attract many investors to invest in Indonesia so that in the end, Indonesia's bargaining power position will increase (Alam, 2020).

The phenomenon that occurs is: On one hand, Indonesia is a very attractive investment destination for investors because of the geographical location on the strategic sea transportation route, the number of productive age population is very large, and the growth of the middle-class population is also quite high, increasing the purchasing power of the middle class from year to year (Riyanto, 2014). But on the other hand, political instability is a real threat in Indonesia; various mass organizations that do not conform to state ideology and acts of terrorism are a tangible manifestation of the existence of such threats.

Since the determinants of political stability is important to acknowledge and control in order to maintain and improve political stability, which will increase the interest of foreign investors to invest, the purpose of this research is to determine the determinant of political stability in Indonesia and to form a model that investors can use to assess the condition of political stability and by the government to maintain political stability. The formation of a political stability model for Indonesia is the novelty of this research.

\section{Literature Review}

The following are cases in a number of countries relating to political instability based on theoretical and literature studies.

\subsection{Regulatory Changes}

The increased of political risk will increase the financial risk of a Multinational Company's Foreign Direct Investment (Dutta, N. and Roy, 2011; Hendarto et al., 2021). One of the most frequent political promises used to win an election is tax regulation (Wagner et al., 2018b). For example, in a presidential election in the US, the candidates debate and promise the imposition of tax rates, which always attract business people and multinational corporations (Wagner et al., 2018a). That is because the tax rate imposed by the winner of the election will directly impact the company's net profit and the company's share price on the stock exchange (Pástor \& Veronesi, 2020; Hendarto et al., 2021).

\subsection{Legal Disputes}

Roe \& Siegel (2011) concluded that the perpetuation of inequality was a fundamental obstacle for international organizations to invest in. Politics and law are often related because the ruling government often issues laws related to its political policies. India is considered one of the countries with high-risk political stability (Wise \& Darmstadt, 2015), and a legal system that harms investors (Aisbett et al., 2018). This is because judges are so rare in India that legal disputes over patents in India take years to resolve (Kahle, 2021). To prosecute counterfeiters is also not easy 
because the country does not have an Act on patents. This situation is very detrimental to multinational companies that have spent a lot of money on research and development.

\subsection{Hostile Takeover of the Company}

De Vaal \& Ebben (2011) stated that economic growth would only occur when political stability and appreciation for ownership rights have been rewarded. Unfortunately, some countries that have experienced political turmoil and caused regime change are Iran, Bolivia, and Venezuela. The new regime forced the hostile takeover of multinational companies because it had a perspective contrary to the old regime towards the existence of multinational companies in their country (Berrios et al., 2011). When there is a presidential election in developing countries, foreign investors and multinational companies delay their investments until it is clear who will lead the country and what the new government's political policies (Chen et al., 2019).

\subsection{Disturbance to Regional Stability}

There are some of the political instability that has occurred in different parts of the world lately (Hakordia, 2019), such as:

1. Trade war between USA and China.

2. The abolition of subsidies in Ecuador which caused a political crisis.

3. Recession in Argentina.

4. The British Exit that will cause eurozone countries to experience an economic slowdown.

5. Tariff wars between the US and countries in the Eurozone that will cause an economic slowdown as well.

6. U.S.-backed Kurdish rebels in Syria are under attack by the Turkish government.

7. Attack on an Iranian oil tanker.

8. The demonstrations demanded an improvement in economic conditions in Iraq.

9. The increase in the number of US troops in Saudi Arabia could trigger suspicions and concerns from Iran.

10. Trade war between South Korea and Japan.

11. People unrest in Hong Kong.

12. Military coup in Myanmar.

Of all the political instability above, the trade war between the USA and China has the greatest risk because of the following:

"The trade war between the US and China begins with the US trade balance experiencing a deficit against China's trade balance (Li et al., 2018). Chinese imported goods in the USA are actually not high-tech goods, and they can even be said to be daily necessities such as pencils, pens, spoons, dinner plates, and other objects made of plastic material. These goods can be made very cheaply in an enormous number because China is mass-producing them on a giant scale. The occurrence of economies of scale due to producing on a giant scale means that the fixed cost per unit of each item produced in China is very small; the impact is that Chinese factories can make goods at very low unit costs and the selling price of the product is very cheap. In addition, the Chinese government's support for producers in China is in the form of lower taxes than in the USA. The level of corruption is reduced to almost zero percent. The Yuan exchange rate against the US Dollar also manages to below, strongly supporting the selling price of this very cheap product. The Yuan exchange rate against the US Dollar remains low, even though China's trade balance has been a surplus against the USA for decades. It is possibly because the Chinese government regulates foreign exchange transactions very tightly. It does not allow speculation on the value of the Yuan against the US currency or other countries' currencies.

On the other hand, US exports to China are in the form of many high-tech products that China can quickly imitate through reverse engineering. China can make smartphones, laptops and even stealth technology through this process. Many manufacturers in the USA also move their factories to China or outsource to factories in China. This has resulted in many factories in the USA closing and laying off their workers in the USA. This is thought to have caused anti-Asian sentiment to occur in the US (Croucher et al., 2020). To make it worse, one candidate in the US presidential election campaign recently made many antiChinese statements (Skonieczny, 2019). In addition, white supremacists' incidence of racial violence against all Asian-faced people in the US has recently risen sharply. The tariff war, which later turned into a trade war, destabilized US internal security and tarnished the US image as a country that advocates for democracy and equality between all races, ethnicities, and religions. The aftermath of this trade war is a dispute between the US and its 
allies, such as Australia and Britain, against China over the South China Sea and ethnic Uighurs. North Korea, which China backs, also frequently conducts nuclear bomb tests and launches cruise missiles at the sea of Japan (Nilsson-wright et al., 2018). These things can cause political instability in Asia, which disrupts the economic growth rate of many countries that drive the world economy, such as Indonesia, South Korea, Japan, Australia, and China."

Abu \& Abd Karim (2015) examines the influence of political instability in western Africa. They concluded that political instability in a country would disrupt the economy in the region around the country. A similar thing is happening in the Korean peninsula, where the decline of political stability has greatly impacted the trajectory of international freighter ships. When North Korea conducted a missile test over Japan, share prices worldwide plummeted due to fears of potential war in the region (Huh \& Pyun, 2018). The killing of political opponents by the Russian government carried out in the UK has also caused political and trade relations between the two countries to stagnate (Gioe et al., 2019). In addition, the Russian government's support for rebels in Georgia and Ukraine and the annexation of the Crimea peninsula from Ukraine have made the political situation in eastern Europe unstable (Tsygankov, 2015).

\subsection{Policy Against Acts of Terrorism and Changes in State Ideology}

Asongu \& Nwachukwu (2015) concluded that political stability has a positive effect on economic growth. The rise of terrorist attacks in Europe and the United States, such as the terrorist attacks in Paris and New York, as well as the overthrow of the government in the events of Arab Springs in the Middle East, have made governments in those countries seem unstable (Katiri et al., 2014). The Southeast Asia region has also experienced political upheaval related to efforts to change the country's ideology. Demonstrations in Hong Kong have crippled the city's economy (Hou et al., 2021). Protests in Thailand demanding an end to the monarchy system have also reduced foreign tourist arrivals (Maliwan \& Mujtaba, 2012). The elections deemed to be not transparent in Malaysia have made investors worried (Gomez, 2016. The actions of many mass organizations contrary to the nation's ideology in Indonesia have made investors postpone their investments (Schulze \& Liow, 2019).

From the study above, it appears that the major risks that multinational companies and foreign investors can experience in the event of political instability are: regulatory changes, legal disputes, forced takeovers of companies, disruption of regional stability, policies against acts of terrorism, and changes in state ideology. Political instability in a country and region impacts increasing business risk, which will cause foreign direct investment to be delayed or canceled. Therefore, business people and government are interested in knowing the determinants of political stability in a country.

\subsection{Research Hypothetical}

This research aims to determine political stability by first conducting a literature study from the results of previous research. Then, descriptive studies describe the results and whether there are gaps between the results of those studies. The next step is to conduct explanatory research to explain the phenomena that occur. The analytical tool used to describe this phenomenon is a statistical tool. Multivariate regression analysis was used to prove the relationship between various variables scientifically. The formation of a model of political stability in Indonesia is what distinguishes this research from previous studies.

This research is conducted because there are still differences in conclusions between various previous research results. This research in Indonesia is essential because Indonesia is one of the countries that is the main destination for foreign investors and multinational companies to invest. The Indonesian government also still needs foreign investment to continue development. From the results of previous researches, it was found that a number of factors influence political stability in a country, namely:

\subsubsection{Rule of Law}

Haider et al. (2011) and Staats \& Biglaiser (2012) concluded that the rule of law significantly affects political stability and foreign direct investment. Weingast (2013), Azeng et al. (2019), and Mele \& Ongaro (2014) also stated that rule of law and legal supremacy is important for maintaining political stability. But Akçoraoğlu \& Kaplan (2017) research states that the influence of the rule of law is not significant on political stability and economic growth. Due to the gaps 
between the different research results, the first hypothesis to be tested in this study is:

H1: The rule of law (ROL) significantly affects political stability (PS).

\subsubsection{Control of Corruption}

Haider et al. (2011) and Azeng et al. (2019) concluded that the increase in corruption significantly affects political instability. The same was summed up by Akçoraoğlu \& Kaplan (2017) and Bahri et al. (2020). However, the research of Ismail \& Rashid (2014) and Adefeso (2018) stated that there is no significant link between increased corruption and political instability. Therefore, the second hypothesis to be tested in this study is:

$\mathrm{H} 2$ : Control of corruption (CC) significantly affects political stability (PS).

\subsubsection{Oil Price}

Khan \& Saqib (2011) research concluded that in the Middle East, the price of petroleum is subsistence by the government to maintain political stability. Esmaeili \& Shokoohi (2011) and Lorusso \& Pieroni (2018) also concluded that rising oil prices positively affected political instability. Similar results were also presented by Arezki \& Brückner (2011). However, Kollias et al. (2013) concluded that the development of petroleum prices did not affect political instability. Due to the gaps between the various research results, the third hypothesis to be tested in this study is:

H3: Oil price (OP) has a significant effect on political stability (PS).

\subsubsection{Inflation Rate}

Khan \& Saqib (2011) concluded that inflation is the cause of political instability in a country. This conclusion is similar to Arezki \& Brückner (2011) findings, which stated that there is a significant influence between the increase of food prices and various anti-government demonstrations. Al-Shammari \& Willoughby (2019) also concluded that inflation is very sensitive to political instability, but Blanco \& Grier (2009) concluded that inflation has no significant effect. Due to the gaps between the various research results, the fourth hypothesis to be tested in this study is:

H4: Inflation rate (INF) has a significant effect on political stability (PS).

\subsubsection{Simultaneous Effect}

From the above research, four factors are considered determinants of political stability, namely: the rule of law, corruption control, oil price, and inflation rate. For examining the simultaneous effect, the following hypothesis is made:

H5: There is a significant simultaneous influence between the rule of law (ROL), control of corruption (CC), oil price (OP), and inflation rate (INF) on political stability (PS).

\subsection{Research Framework}

Based on the hypothesis formed from the existence of gaps from the results of previous studies, the following research framework can be formed:

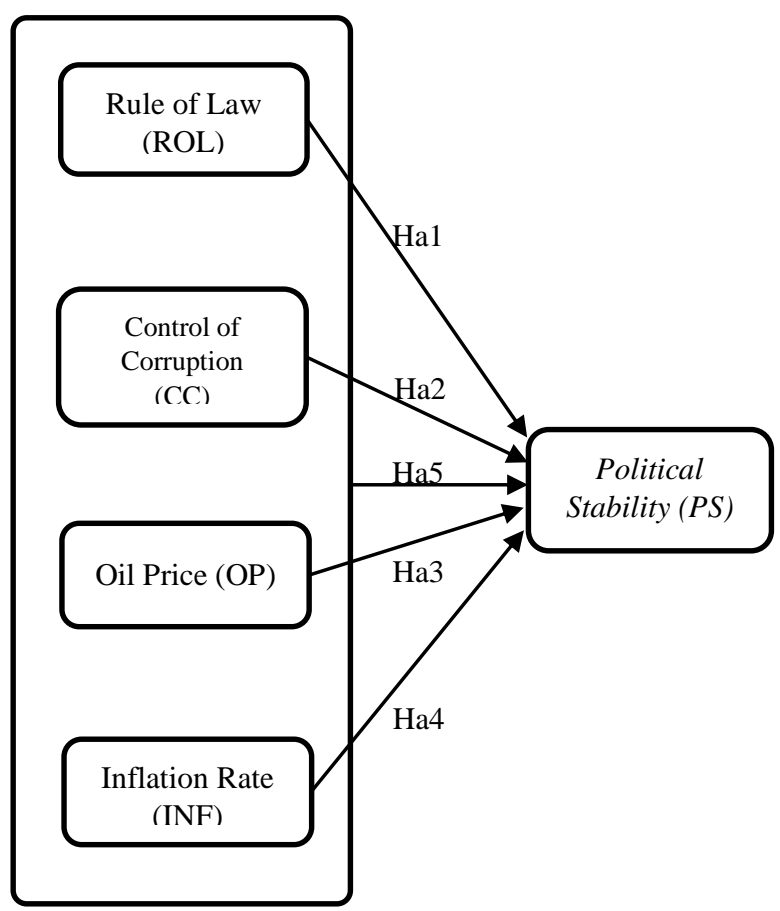

Figure 1. Research Framework

\section{Methods}

As stated in Table 1, all data is secondary data taken from reliable sources, known in the business world such as oil price data taken from www.investing.com (methodology can be seen www.investopedia.com/articles/economics/08/de termining-oil-prices.asp.). Data for the Indonesian inflation rate was taken from www.bi.go.id (the methodology can be seen www.bi.go.id/id/fungsiutama/moneter/inflasi/Default.aspx). Data for 
political stability, the rule of law, and corruption control was taken from www.bbvaresearch.com, created by Worldwide Governance Indicators (WGI). At info.worldbank.org/governance/wgi/, it can be seen that WGI has been providing data for a long period, namely from 1996-2019. The data was taken from a number of survey institutes, think tanks, non-governmental organizations, international organizations, and private sector firms in 200 countries. Methodology can be seen info.worldbank.org/governance/wgi/Home/Docu ments\#wgiAggMethodology. These data are available in scale ratio, so the data can be processed using multivariate regression.

Descriptive methods and descriptive studies were used in this research. Secondary data were obtained from 3 websites www.investing.com, www.bbvaresearch.com, and www.bi.go.id. The population of the data were taken from January 2015 to December 2019. The data were taken from January 2015 because this period was the farthest period that still had complete data related to all the variables to be studied. The data for 2020 were not included in this study because of the Covid-19 pandemic, which caused anomalies in a number of data, such as negative crude oil prices and a sudden drop in inflation due to decreased purchasing power. Therefore, the dependent variable in this study is political stability, while the independent variables used are the rule of law, control of corruption, oil price, and inflation rate. Sampling was conducted based on systematic random sampling with monthly time intervals. Multivariable regression models were used with a significance level of $5 \%$ on the t-test.

Table 1. Source of Variables

\begin{tabular}{cllll}
\hline No & Var. & $\begin{array}{c}\text { Data } \\
\text { Type }\end{array}$ & Period & Data Source \\
\hline 1 & PS & Ratio & Monthly & www.bbvaresearch.com \\
2 & ROL & Ratio & Monthly & www.bbvaresearch.com \\
3 & CC & Ratio & Monthly & www.bbvaresearch.com \\
4 & OP & Ratio & Monthly & www.investing.com \\
5 & INF & Ratio & Monthly & www.bi.go.id \\
\hline
\end{tabular}

Source: Results of secondary data processing using software (2021)

Based on the several literature reviews, the equation model that influences political stability in Indonesia is:

$$
\begin{aligned}
& \mathrm{PS}=\beta_{0}+\beta_{1} \cdot \mathrm{ROL}_{\mathrm{t}}+\beta_{2} \cdot \mathrm{CC}_{\mathrm{t}}+\beta_{3} \cdot \mathrm{OP}_{\mathrm{t}}+\beta_{4} \cdot \mathrm{INF}_{\mathrm{t}}+ \\
& \mu_{\mathrm{t}}
\end{aligned}
$$

Notes:

$$
\begin{array}{ll}
\beta_{0} & : \text { Intercept } \\
\beta_{1,} \beta_{2,} \beta_{3}, \beta_{4} & \text { : Coefficient } \\
\text { PS } & : \text { Political Stability }
\end{array}
$$

$\begin{array}{ll}\text { ROL } & : \text { Rule of Law } \\ \text { CC } & : \text { Corruption Control } \\ \text { OP } & : \text { Oil Price } \\ \text { INF } & : \text { Inflation Rate } \\ \mu & : \text { Term of Error } \\ t & : \text { Time Period }\end{array}$

\section{Results}

\subsection{Assumptions of Classical Model Tests}

The assumptions of classical model tests were used to guarantee a linear regression model meets the Best Linear Unlimited Estimation criteria,

\subsubsection{Normality Test}

Normality test results showed the $\mathrm{p}$-value $=$ $0.086>0.05$. This means that the error term is believed to be distributed normally with a $95 \%$ confidence level.

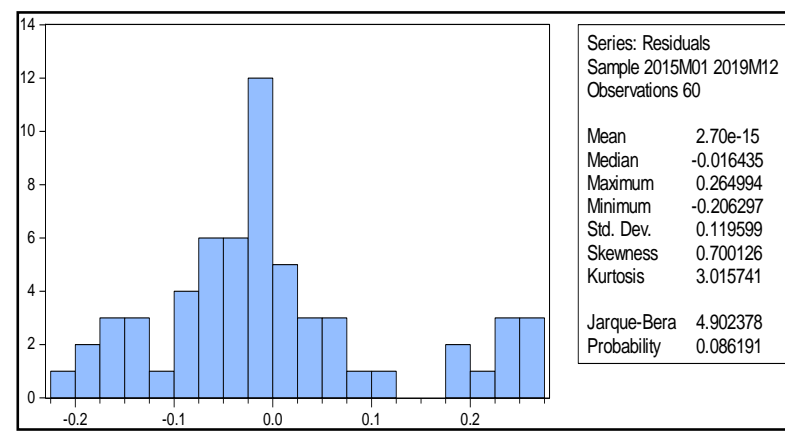

Figure 2. Graph of Normality Test

Source: Results of secondary data processing using software (2021)

\subsubsection{Heteroscedasticity Test}

Heteroscedasticity Test results indicate no heteroscedasticity problem because the test results showed a probability of Chi-Square $>0.05$. So, with a $95 \%$ confidence level, it can be concluded there is no heteroscedasticity.

Table 2. Heteroscedasticity Test: Breusch-PaganGodfrey

\begin{tabular}{lcll}
\hline F-statistic & 1.612713 & Prob. F(4,55) & 0.1841 \\
\hline $\begin{array}{l}\text { Obs*R- } \\
\text { squared }\end{array}$ & 6.298548 & $\begin{array}{l}\text { Prob. Chi- } \\
\text { Square(4) }\end{array}$ & 0.1779 \\
\hline $\begin{array}{l}\text { Scaled } \\
\text { explained } \\
\text { SS }\end{array}$ & 5.334186 & $\begin{array}{l}\text { Prob. Chi- } \\
\text { Square(4) }\end{array}$ & 0.2547 \\
\hline
\end{tabular}

Source: Results of secondary data processing using software (2021)

\subsubsection{Multicollinearity Test}

From the results of the Multicollinearity Test, it can be concluded there is no multi- 
collinearity because all Variance Inflation Factors figures are less than 10 .

Table 3. Multicollinearity Test

\begin{tabular}{ccc}
\hline Variable & Coefficient Variance & Centered VIF \\
\hline C & 3.212824 & NA \\
CC & 0.009985 & 3.069229 \\
ROL & 0.014242 & 3.774946 \\
OP & 0.014852 & 2.419012 \\
INF & 0.010941 & 3.65595 \\
\hline
\end{tabular}

Source: Results of secondary data processing using software (2021)

\subsubsection{Autocorrelation Test}

From the results of the Autocorrelation Test, it can be concluded there is no autocorrelation because the test results showed a probability of Chi-Square > 0.05. So, with a 95\% confidence level, it can be concluded there is no autocorrelation.

Table 4. Autocorrelation Test: Breusch-Godfrey Serial Correlation LM Test

\begin{tabular}{llll}
\hline F-statistic & 1.801092 & Prob. F(2,51) & 0.1755 \\
\hline $\begin{array}{l}\text { Obs*R- } \\
\text { squared }\end{array}$ & 3.892315 & $\begin{array}{l}\text { Prob. Chi- } \\
\text { Square(2) }\end{array}$ & 0.1428 \\
\hline
\end{tabular}

\subsection{Multivariable Regression Test}

The result of data processing is in the following table:

Table 5. The Result of Multivariable Regression Test

Dependent Variable: PS

Method: Least Squares

Sample: 2015M01 2019M12

Included observations: 60

\begin{tabular}{lccc}
\hline \multicolumn{1}{c}{ Variable } & Coefficient & Std. Error & Prob. \\
\hline C & 5.848956 & 1.792435 & 0.0019 \\
ROL & 0.277369 & 0.119341 & 0.0238 \\
CC & -0.457863 & 0.099925 & 0 \\
OP & -0.413612 & 0.12187 & 0.0013 \\
INF & 0.122297 & 0.104602 & 0.2474 \\
\hline R-squared & 0.332454 & F-statistic & 6.847842 \\
\hline Adjusted R- & & & \\
squared & 0.283906 & Prob & 0.000151 \\
\hline
\end{tabular}

Source: Results of secondary data processing using software (2021)

From the above table the equation can be formed as:

$$
\begin{aligned}
\mathrm{PS}= & 5.848956+0.277369 \mathrm{ROL}_{\mathrm{t}}-0.457863 \mathrm{CC}_{\mathrm{t}} \\
& -0.413612 \mathrm{OP}_{\mathrm{t}}+0.122297 \mathrm{INF}_{\mathrm{t}}
\end{aligned}
$$

Partially, the rule of law has a significant effect on the political stability in Indonesia. This result is in line with several researchers' conclusions, such as Haider et al. (2011), Staats \& Biglaiser (2012), Weingast (2013), Azeng et al. (2019), and Mele \& Ongaro (2014). The coefficient of the rule of law has a positive sign, meaning that the increase of implementation of the rule of law will increase political stability and vice versa. The Indonesian nation consists of various tribes, races, and religions; this, on the one hand, increases cultural wealth but, on the other hand, can facilitate the onset of disputes, which is why increasing the rule of law will increase political stability.

Partially, corruption control has a significant effect on the political stability in Indonesia; this result is in line with several researches' conclusion such as: Haider et al. (2011), Azeng et al. (2019), Akçoraoğlu \& Kaplan (2017), and Bahri et al. (2020). The coefficient of corruption control has a negative sign, meaning that the increase of implementation of corruption control will decrease political stability and vice versa. In recent years, the handling of corruption by Komisi Pemberantasan Korupsi (Corruption Eradication Commission) has arrested many ministers, governors, mayors, regents, and members of the house of representatives who are still actively serving in the government. These government officials are generally high-ranking officials in political parties, so when a political party official is arrested for corruption, the political party's support for the ruling government will be reduced. Public confidence in political parties and the government will also be reduced so that political stability will also decrease.

Partially, the oil price has a significant effect on the political stability in Indonesia; this result is in line with several researches' conclusion such as Khan \& Saqib (2011), Esmaeili \& Shokoohi (2011), Lorusso \& Pieroni (2018), and Arezki \& Brückner (2011). The oil price coefficient has a negative sign, meaning that the oil price increase will decrease political stability and vice versa. Users of oil in Indonesia for motor vehicles are very large. Students, commuter workers, distribution companies, motorbike taxis dominate the means of transportation. The increase in oil prices will also make it difficult for small-medium enterprises to become the Indonesian economy's backbone (Wardhana, 2018). The increase in oil prices in Indonesia is usually greeted with demonstrations by students and labor organizations. That would certainly disrupt political stability. 
Partially, the inflation rate has no significant effect on the political stability in Indonesia; this result is in line with the Blanco \& Grier (2009) conclusion. Furthermore, every year, civil servants in Indonesia earn thirteenth salaries and additional salaries on religious holidays; this is expected to maintain the purchasing power of the public despite inflation. Therefore, the increase in inflation has no significant effect on political stability.

Simultaneously, the rule of law, corruption control, oil price, and inflation rate significantly affect political stability in Indonesia; this can be seen from prob (F-statistic) $<0.05$. Partially, the rule of law, corruption control, and oil price significantly affect political stability because it has a p-value $<0.05$, while the inflation rate has no significant effect on political stability in Indonesia.

\section{Discussion}

The increase in the rule of law has a significant effect on the improvement of political stability. A decrease in the level of criminality will increase the sense of security and increase trust in the government. Conversely, when the crime rate increases, the public feels unsafe and decreases public confidence in government policy. Thus, a protracted decline in public confidence in the government's policies could disrupt political stability.

The increase in corruption control has a significant effect on the decline of political stability. This particular thing that happened in Indonesia can be explained as follows: the handling of corruption by Komisi Pemberantasan Korupsi (Corruption Eradication Commission) in recent years has arrested many ministers, governors, mayors, regents, and members of the house of representatives who are still actively serving in the government. These government officials are generally high-ranking officials in political parties, so when a political party official is arrested for corruption. Public confidence in political parties and the government will also be reduced to decrease political stability.

The increase in oil price has a significant effect on the decrease of political stability. Indonesia is currently a net importer of oil, so increasing the world oil price will increase transportation costs, erode the country's foreign exchange reserves, and erode the number of government subsidies to the poor. All of these things can cause unrest among the public and trigger demonstrations that disrupt political stability.

The inflation rate has no significant effect on political stability. In the last ten years, the Indonesian government has succeeded in suppressing rising inflation. Still, the inflation rate setting does have two functions: increasing the purchasing power of the public and increasing the attractiveness of investors/entrepreneurs. Every year, civil servants in Indonesia earn thirteenth salaries and additional salaries on religious holidays; this is expected to maintain the purchasing power of the public despite inflation. Therefore, the increase in inflation has no significant effect on political stability.

The implication of this research is the formation of a multivariable regression model for political stability in Indonesia, which will be useful for both foreign investors and the government in assessing and maintaining the level of political stability in Indonesia to maintain investment attractiveness. Practically the Indonesian government can pay more attention to various independent variables that have a significant effect on dependent variables in the equation to maintain political stability in Indonesia. At the same time, practical implication for foreign investors is that they can estimate the direction of political stability in Indonesia when there is a change in one or more of those independent variables.

\section{Conclusions}

Determinants of political stability in a country may differ in influence and level of signification from other countries. It depends on the culture of the community, local customs, and the current situation in the country. Therefore, multinational companies and foreign investors must constantly monitor and measure the level of political stability in which their companies are located. This research on the determinants of political stability in Indonesia has strengthened the previous findings: the rule of law has a significant positive effect, and the oil price has a significant negative effect on political stability in Indonesia. The novelties of this research are establishing a model of political stability for Indonesia and explaining why increased corruption control actually has a negative impact on political stability in Indonesia. This finding should not be interpreted as an appeal for the KPK to lower its performance in arresting corruptors. In fact, politicians in government positions realize 
that any corrupt actions will eventually be revealed and will damage the government's image to disrupt political stability. Therefore, it is expected that all behave honestly and obey the applicable law.

The limitations of this study are that some important data relating to political stability, the rule of law, and control of corruption for Indonesia do not have a long enough period recorded in the secondary data that can be found. However, suppose in the future these data can be completed and expanded. In that case, the determinants of political stability and the multivariable regression model for political stability in Indonesia can hopefully be further developed.

\section{References}

Abdelaty, H., \& Esmail, H. (2016). Impact of Terrorism and Instability on The Tourism Industry in Egypt and Tunisia After Revolution. The Business and Management Review, 7(5), 469-475. search.proquest.com. proxy.grenoble-em.com/docview/

1817996152/2C010B76BBD44AECPQ/5?acc ountid $=42864$

Abu, N., \& Abd Karim, M. Z. (2015). The Causal Relationships Among Corruption, Political Instability, Economic Development and Foreign Aid: Evidence from The Economic Community of West African States. Journal of Applied Economic Sciences, X (31). pp. 20-33. ISSN 2393-5162. repo.uum.edu.my/id/eprint/ 15104

Adefeso, H. (2018). Corruption, Political Instability and Development Nexus in Africa: A Call for Sequential Policies Reforms. 85277.

Aisbett, E., Busse, M., \& Nunnenkamp, P. (2018). Bilateral Investment Treaties as Deterrents of Host-Country Discretion: The Impact of Investor-State Disputes on Foreign Direct Investment in Developing Countries. Review of World Economics, 154(1), 119-155. doi.org/10.1007/s10290-017-0285-1

Akçoraoğlu, A., \& Kaplan, E. A. (2017). Political Instability, Corruption, and Economic Growth: Evidence from A Panel of OECD Countries. Business and Economics Research Journal, 8(3), 363-377. doi.org/10.20409/berj.2017.55

Al-Shammari, N., \& Willoughby, J. (2019). Determinants of Political Instability Across Arab Spring Countries. Mediterranean Politics, 24(2), 196-217. doi.org/10.1080/ 13629395.2017.1389349
Alam, F. (2020). Ekonomi Politik Investasi Perusahaan Multinasional di Era Pemerintahan Joko Widodo. Politika: Jurnal Ilmu Politik, 11(2), 131-147. doi.org/10.14710/politika. 11.2.2020.131-147

Arezki, R., \& Brückner, M. (2011). Oil Rents, Corruption, and State Stability: Evidence from Panel Data Regressions Rabah Arezki and Markus Brückner Oil Rents, Corruption, and State Stability: Evidence From Panel Data Regressions.

Asongu, S. A., \& Nwachukwu, J. (2015). A Good Turn Deserves Another: Political Stability, Corruption and Corruption-Control. SSRN Electronic Journal, 1-16. doi.org/10.2139/ ssrn.2662731

Azeng, T. F., Yogo, T. U., Kim, D. H., Chen, T. C., Lin, S. C., African Development Bank Group, Abé Ndjié, A., Atangana Ondoa, H., Ngoa Tabi, H., Gatti, D., Rault, C., Vaubourg, A. G., Bayar, Y., Feldmann, H., Ayadi, R., Naceur, S. Ben, Goaied, M., Shabbir, G., Anwar, S., ... Dutta, Probal and Bose, S. (2019). AFDB Working Paper Series No 171 Youth Unemployment and Political Instability in Selected Developing Countries. Economic Policy, March(5), 1491-1496. doi.org/ 10.1080/0023656X.2019.1645320\%0Awww. afdb.org/s.pitamber@afdb.org\%0Ahttp://doi. org/10.1080/17487870.2018.1451750\%0Ahtt p://www.afdb.org/fileadmin/uploads/afdb/Do cuments/Publications/Working_Paper_171__Youth_Unemployment_and_Political_Instab

Bahri, M., Sakka, O., \& Kallal, R. (2020). The Impact of Corruption on The Export Intensity of Smes in Tunisia: Moderating Effects of Political Instability and Regulatory Obstacles. Journal of Entrepreneurship in Emerging Economies. doi.org/10.1108/JEEE-03-20200055

Berrios, R., Marak, A., \& Morgenstern, S. (2011). Explaining Hydrocarbon Nationalization in Latin America: Economics and Political Ideology. Review of International Political Economy, 18(5), 673-697. doi.org/10.1080/ 09692290.2010 .493733

Blanco, L., \& Grier, R. (2009). Long Live Democracy: The Determinants of Political Instability in Latin America. Journal of Development Studies, 45(1), 76-95. doi.org/10.1080/00220380802264788

Chen, K., Nie, H., \& Ge, Z. (2019). Policy Uncertainty and FDI: Evidence from National Elections. Journal of International Trade and Economic Development, 28(4), 419-428. 
doi.org/10.1080/09638199.2018.1545860

Cleeve, E. (2012). Political and Institutional Impediments to Foreign Direct Investment Inflows to Sub-Saharan Africa. Thunderbird International Business Review, 54(4), 469477. doi.org/10.1002/tie

Croucher, S. M., Nguyen, T., \& Rahmani, D. (2020). Prejudice Toward Asian Americans in the Covid-19 Pandemic: The Effects of Social Media Use in the United States. Frontiers in Communication, 5(June), 1-12. doi.org/ 10.3389/fcomm.2020.00039

De Vaal, A., \& Ebben, W. (2011). Institutions and the Relation between Corruption and Economic Growth. Review of Development Economics, 15(1), 108-123. doi.org/10.1111/ j.1467-9361.2010.00596.x

Dewi, S. F. (2017). Sosiologi Politik (1st ed.). Gre Publishing. books.google.co.id/books?hl=id\& $\mathrm{lr}=\& \mathrm{id}=\mathrm{WE} 9 \mathrm{UDw}$ AAQBAJ\&oi=fnd $\& p g=\mathrm{PR}$ $3 \&$ ots $=$ TCDVG0gjR2\&sig=O8dftmrkYpi8RnUiEmCf-lPXxk\&redir_esc=y\#v= onepage \&q\&f=false

Dutta, N. and Roy, S. (2011). Foreign Direct Investment, Financial Development and Political Risks. Www.jstor.org/stable/ 23215253 Foreign Direct Investment. The Journal of Developing Areas, 44(2), 303-327.

Esmaeili, A., \& Shokoohi, Z. (2011). Assessing The Effect of Oil Price on World Food Prices: Application of Principal Component Analysis. Energy Policy, 39(2), 1022-1025. doi.org/10.1016/j.enpol.2010.11.004

Gioe, D. V., Goodman, M. S., \& Frey, D. S. (2019). Unforgiven: Russian Intelligence Vengeance as Political Theater and Strategic Messaging. Intelligence and National Security, 34(4), 561-575. doi.org/10.1080/ 02684527.2019.1573537

Gomez, E. T. (2016). Resisting the Fall: The Single Dominant Party, Policies and Elections in Malaysia. Journal of Contemporary Asia, 46(4), 570-590. doi.org/10.1080/00472336. 2016.1192214

Hadi, K. (2016). Korupsi Birokrasi Pelayanan Publik di Era Otonomi Daerah. Jurnal Penelitian Politik, 7(1), 20. ejournal.lipi.go.id/ index.php/jppol/article/download/512/320

Haider, A., Ud Din, M., \& Ghani, E. (2011). Consequences of Political Instability, Governance and Bureaucratic Corruption on Inflation and Growth: The Case of Pakistan. Pakistan Development Review, 50(4), 773807. doi.org/10.30541/v50i4iipp.773-807
Hakordia. (2019). Kementerian Koordinator Bidang Perekonomian Perkembangan dan Tantangan Investasi di Indonesia. www.kpk.go.id/images/Perkembangan-danTantangan-Investasi---Menko-Perekonomian--HAKORDIA-2019.pdf

Haryanti, R. (2019). Kondisi Politik Stabil Jadi Ladang Investasi Menarik. properti.kompas. com/read/2019/06/28/170000521/kondisipolitik-stabil-jadi-ladang-investasi-menarik

Hendarto, K., Anastasia, N., and Basana, S.R. (2021). The Effect of Financial Literacy, Financial Risk Tolerance, and Financial Socialization Agents on Stock Investment Decision in The Millennial Generation. International Journal of Business Studies, 4(1),11-22, doi.org/10.9744/ijbs. 4.1.11-22

Hou, W. K., Hall, B. J., Liang, L., Li, T. W., Liu, H., \& Galea, S. (2021). Probable Depression and Suicidal Ideation in Hong Kong Amid Massive Civil Unrest. Annals of Epidemiology, 54(x xxx), 45-51. doi.org/10.1016/ j.annepidem.2020.09.006

Huh, I., \& Pyun, J. H. (2018). Does Nuclear Uncertainty Threaten Financial Markets? The Attention Paid to North Korean Nuclear Threats and Its Impact on South Korea's Financial Markets. Asian Economic Journal, 32(1), 55-82. doi.org/10.1111/asej.12142

Ismail, A., \& Rashid, K. (2014). Time Series Analysis of The Nexus Among Corruption, Political Instability and Judicial Inefficiency In Pakistan. Quality and Quantity, 48(5), 27572771. doi.org/10.1007/s11135-013-9922-5

Jensen, N. M. (2003). Democratic Governance and Multinational Corporations: Political Regimes and Inflows of Foreign Direct Investment. International Organization, 57(3), 587-616. doi.org/10.1017/s0020818303573040

Kahle, A. (2021). State Law, Dispute Processing, and Legal Pluralism: Unspoken Dialogues from Rural India. The Journal of Legal Pluralism and Unofficial Law, O(0), 1-5. doi.org/10.1080/07329113.2021.1904578

Katiri, L. El, Fattouh, B., \& Mallinson, R. (2014). The Arab Uprisings and MENA Political Instability: Implications for Oil \& Gas Markets. In The Oxford Institute for Energy Studies (Issue March).

Khan, S. U., \& Saqib, O. F. (2011). Political Instability and Inflation in Pakistan. Journal of Asian Economics, 22(6), 540-549. doi.org/ 10.1016/j.asieco.2011.08.006 
Kollias, C., Kyrtsou, C., \& Papadamou, S. (2013). The Effects of Terrorism and War on The Oil Price-Stock Index Relationship. Energy Economics, 40, 743-752. doi.org/10.1016/ j.eneco.2013.09.006

Li, C., He, C., \& Lin, C. (2018). Economic Impacts of the Possible China-US Trade War. Emerging Markets Finance and Trade, 54(7), 1557-1577. doi.org/10.1080/1540496X.2018. 1446131

Lorusso, M., \& Pieroni, L. (2018). Causes and Consequences of Oil Price Shocks on The UK Economy. Economic Modelling, 72(2), 223236. doi.org/10.1016/j.econmod.2018.01.018

Makki, S. (2019). Situasi Politik Tekan Laju Investasi Jadi 4,21 Persen. www.cnnindonesia. com/ekonomi/20191105133715-532445748/situasi-politik-tekan-laju-investasijadi-421-persen

Maliwan, R., \& Mujtaba, B. G. (2012). Tourist Attitudes toward Traveling in Thailand after the Political Demonstrations and Protests. Journal of Management and Sustainability, 2(1), 16-28. doi.org/10.5539/jms.v2n1p16

Mele, V., \& Ongaro, E. (2014). Public Sector Reform in a Context of Political Instability: Italy 1992-2007. International Public Management Journal, 17(1), 111-142. doi.org/10.1080/10967494.2013.849168

Musibah, A. S., Shahzad, A., \& Bt Fadzil, F. H. (2015). Impact of Foreign Investment in The Yemen's Economic Growth: The Country Political Stability As A Main Issue. Asian Social Science, 11(4), 102-116. doi.org/ 10.5539/ass.v11n4p102

Nilsson-wright, J., Nilsson-wright, J., \& John-, B. I. O. (2018). Japan's response to North Korea. 1945(August 2017), 2017-2019.

Pástor, L., \& Veronesi, P. (2020). Political Cycles and Stock Returns. Journal of Political Economy, 128(11), 4011-4045. doi.org/ $10.1086 / 710532$

Riyanto, A. (2014). Implikasi Politik terhadap Iklim Investasi di Indonesia. businesslaw.binus.ac.id/2014/10/05/implikasi-politikterhadap-iklim-investasi-di-indonesia/

Roe, M. J., \& Siegel, J. I. (2011). Political Instability: Effects on Financial Development, Roots in The Severity Of Economic Inequality. Journal of Comparative Economics, 39(3), 279-309. doi.org/10.1016/j.jce.2011.02.001

Rudolfsen, I. (2021). Food Price Increase and Urban Unrest: The Role of Societal Organizations. Journal of Peace Research, 58(2), 215-230. doi.org/10.1177/0022343319
899705

Schulze, K. E., \& Liow, J. C. (2019). Making Jihadis, Waging Jihad: Transnational and Local Dimensions of The Isis Phenomenon in Indonesia and Malaysia. Asian Security, 15(2), 122-139. doi.org/10.1080/14799855.2018. 1424710

Setyaningrum, P.M. (2019). Kondisi Politik dalam Negeri Perbesar Ancaman Indonesia Terkena Resesi Ekonomi. www.warta ekonomi.co.id/read249872/kondisi-politikdalam-negeri-perbesar-ancaman-indonesiaterkena-resesi-ekonomi

Sicca, S.P. (2018). BKPM: Kondisi Politik Indonesia Masih Kondusif untuk Investasi. tirto.id/bkpm-kondisi-politik-indonesia-masih -kondusif-untuk-investasi-cSvk

Skonieczny, A. (2019). Populism and World Politics. In Populism and World Politics. Springer International Publishing. doi.org/ 10.1007/978-3-030-04621-7

Staats, J. L., \& Biglaiser, G. (2012). Foreign Direct Investment in Latin America: The Importance of Judicial Strength and Rule of Law. International Studies Quarterly, 56(1), 193-202. doi.org/10.1111/j.1468-2478.2011. 00690.x

Tjandrasa, B. B. (2019). Modeling Business Performance and Macroeconomic Factors to Explain Stock Market Returns in LQ45 Indonesia Stock Exchange (IDX). Petra International Journal of Business Studies, 2(1), 38-65. doi.org/10.9744/ijbs.2.1.38-65

Tjandrasa, B.B., Ariwibowo, A. and Jewarut, R. (2020). The Influence of Inflation Rate, Exchange Rate, Corruption Control, and Political Stability to Indonesian Goverment Bond Yield. International Journal of Business Studies, 3(1), 18-22, doi.org/10.9744/ijbs. 3.1.18-22

Tsygankov, A. (2015). Vladimir Putin's last stand: The sources of Russia's Ukraine policy. PostSoviet Affairs, 31(4), 279-303. doi.org/ 10.1080/1060586X.2015.1005903

Wagner, A. F., Zeckhauser, R. J., \& Ziegler, A. (2018a). Company Stock Price Reactions to The 2016 Election Shock: Trump, Taxes, and Trade. Journal of Financial Economics, 130(2), 428-451. doi.org/10.1016/j.jfineco. 2018.06.013

Wagner, A. F., Zeckhauser, R. J., \& Ziegler, A. (2018b). Unequal Rewards to Firms: Stock Market Responses to the Trump Election and the 2017 Corporate Tax Reform. AEA Papers and Proceedings, 108, 590-596. doi.org/ 
10.1257/pandp.20181091

Wardhana, D. Y. (2018). Good Corporate Governance Practices in Family Business: A Case Study in Indonesia. Petra International Journal of Business Studies, 1(1), 35-44. doi.org/10.9744/ijbs.1.1.35-44

Wardojo, M. F. (2018). Kedudukan Komisi Pemberantasan Korupsi Sebagai Lembaga Negara. Legal Standing: Jurnal Ilmu Hukum, 2(1), 73. doi.org/10.24269/ls.v2i1.1008

Wattimena, H. (2016). Perkembangan Tindak Pidana Korupsi Masa Kini dan Pengembalian Kerugian Keuangan Negara. Tahkim, XII(2), 126.

Weingast, B. R. (2013). Why Developing Countries Prove So Resistant to The Rule of Law. Global Perspectives on the Rule of Law, 28-52. doi.org/10.4324/9780203870594

Wise, P. H., \& Darmstadt, G. L. (2015). Confronting Stillbirths and Newborn Deaths in
Areas of Conflict and Political Instability: A Neglected Global Imperative. Paediatrics and International Child Health, 35(3), 220-226. doi.org/10.1179/2046905515Y.0000000027

Wuryasti, F. (2019). Kondisi Politik dan Ekonomi Positif Tarik Investor ke Indonesia. mediaindonesia.com/ekonomi/246405/kondisi -politik-dan-ekonomi-positif-tarik-investorke-indonesia

www.bbvaresearch.com

www.bi.go.id

www.investing.com

www.bi.go.id/id/fungsi-utama/moneter/inflasi/ Default.aspx

www.investopedia.com/articles/economics/08/de termining-oil-prices.asp.

info.worldbank.org/governance/wgi/

info.worldbank.org/governance/wgi/Home/Docu ments\#wgiAggMethodology 